$7-1-2013$

\title{
When Institutional Work Backfires: Organizational Control Of Professional Work In The Pharmaceutical Industry
}

Jagdip Singh

Case Western Reserve University, jagdip.singh@case.edu

Rama K. Jayanti

Cleveland State University, r.jayanti@csuohio.edu

Follow this and additional works at: https://engagedscholarship.csuohio.edu/bus_facpub

Part of the Business Administration, Management, and Operations Commons, and the Organizational Behavior and Theory Commons

How does access to this work benefit you? Let us know!

\section{Publisher's Statement}

This is the accepted version of the following article: Singh, J \& Jayanti, R.K. (2013). When institutional work backfires: Organizational control of professional work in the pharmaceutical industry. Journal of Management Studies, 50(5), 900-929. doi: 10.1111/joms.12022, which has been published in final form at http://onlinelibrary.wiley.com/doi/10.1111/joms.12022/abstract

\section{Original Published Citation}

Singh, J \& Jayanti, R.K. (2013). When institutional work backfires: Organizational control of professional work in the pharmaceutical industry. Journal of Management Studies, 50(5), 900-929. doi: 10.1111/ joms.12022

This Article is brought to you for free and open access by the Monte Ahuja College of Business at EngagedScholarship@CSU. It has been accepted for inclusion in Business Faculty Publications by an authorized administrator of EngagedScholarship@CSU. For more information, please contact library.es@csuohio.edu. 


\section{When Institutional Work Backfires: Organizational Control of Professional Work in the Pharmaceutical Industry}

\section{Jagdip Singh and Rama K. Jayanti}

Case Western Reserve University, Cleveland State University

ABSTRACT Integrating institutional and role theories, this paper develops a Logics-RolesAction (LRA) framework for understanding how for-profit organizations structure institutional work to managerially control the work of professionals they employ. Structurally, this institutional work involves three elements: (1) internalizing pluralistic logics (logics); (2) institutionalizing distinct roles embedded in these logics (roles); and (3) scripting goal-oriented role enactment plans (action). An empirical examination of the LRA framework in the pharmaceutical industry evidences four distinct organizational strategies that script role enactments of sales professionals in their interactions with physicians. Each strategy is intended to reaffirm prevailing institutional logics, but eventually backfires by disrupting the very institutional structures that it seeks to maintain and replicate. We show that this disruptive effect is mediated by changes in the social knowledge of institutional work. We close with theoretical and managerial implications for organizational structuring of institutional work and dynamics of institutional change.

Keywords: institutional change, institutional work, logics, organization, pharmaceutical marketing, professional work, role enactment

\section{INTRODUGTION}

Expansion in the employment and control of professionals by for-profit organizations is an unmistakable characteristic of the modern age (Brint, 1994; Broadbent et al., 1997; Brock, 2006). Organizations are managing ever-larger swaths of professional work (Leicht and Fennell, 1997), and there is growing recognition that once employed, professionals more or less cede their free agent status and submit to organizational edict for maximizing economic returns (Scott, 2008, p. 220). Suddaby et al. (2009, p. 424) agree and note that professional work is appropriated by organizations with 'growing influence of the logic of managerialism in the profession'. Because professionals 
are bound by a fiduciary obligation to place client interest above all else, organizational control of professional work sharpens the focus on the potentially competing logics that govern employed professionals (Cooper and Robson, 2006; von Nordenflycht, 2010). How do commercial interests and fiduciary obligations coexist in for-profit organizations? How do such organizations reconcile conflicts? What are the implications of institutional work that structures and controls professional work? Despite the significance of and challenges posed by such questions, Scott (2008, p. 220) laments that, while free professionals have been well studied, scant attention has been paid to 'institution bound' professionals whose autonomy is constrained by organizational edict. As a result, little is known about the nature, strategy, and scope of organizational efforts to structure and control the work of professionals they employ.

This paper aims to fill the preceding gap in the literature by proposing a LogicsRoles-Action (LRA) framework for studying organizational control of professional work that integrates institutional and role theory perspectives. A central assertion of the proposed framework is that organizations draw from widely available institutional logics to structure and direct professional roles for desired action and valued outcomes and, in turn, professional action is interpreted by clients and publics as institutional work with potential to legitimize, stabilize, disrupt, or innovate prevalent institutional structures and fields. The conception of roles provides a theoretical bridge for understanding how organizations situate and scaffold institutional work - that is, exert agency in structuring the interplay between institutional logics and actions of employed professionals. Barley and Tolbert (1997, p. 99) recognized that role scripts are critical pivots in understanding the recursive interdependence between institutions and actions. We build on this foundation by considering how organizations structure these pivots in structuring institutional work to motivate, direct, and control the professionals they employ.

In so doing, we incorporate the pluralistic institutional logics - communal and commercial - that characterize institution bound professionals employed by for-profit organizations (Dunn and Jones, 2010; Leicht and Fennell, 1997; Scott, 2008; Suddaby et al., 2009). Consistent with past research (Battilana and Dorado, 2010; Dunn and Jones, 2010; Glynn and Lounsbury, 2005), we sharpen the contrast between logics and show how these contrasting logics constrain and bolster the agency of actors to enact action routines that stabilize, disrupt, or innovate institutional orders and fields (Sitkin and Sutcliffe, 1991; Suddaby et al., 2009). However, unlike past research that has considered actors as individuals or groups, we focus on organizations as actors engaged in institutional work. The reach and reign of organizational agency may be constrained by professionals' relative success in wrestling autonomy over decisional rights (Suddaby et al., 2009). For instance, physicians employed by for-profit hospitals typically enjoy substantial power and autonomy in work-related decisions, while pharmacists employed in the same context usually lack similar power or autonomy. More so than the former, the latter situation is relevant to our theorizing.

We extend past research on action-institution interdependence by identifying conditions that allow institutional work by organizations to stick, resulting in institutional stability, or backfire, resulting in institutional change. Several studies have examined the role of institutional work in precipitating institutional change (Greenwood and Suddaby, 2006; Haveman and Rao, 2006; Rao et al., 2003). Typically, these studies focus on institutional change and 
examine its roots in actors' efforts to situate and scaffold institutional work by 'translating exogenous shocks ... and disruptive events' or internalizing 'peripheral positions ... and boundary [perspectives]' (Zietsma and Lawrence, 2010, p. 189). Our study considers an opposite, heretofore neglected, situation. That is, how institutional work by organizations that is intended to reinforce institutional logics and bolster institutional stability can nevertheless precipitate institutional change through mechanisms rooted in social knowledge. In this sense, we consider how institutional work by organizations may backfire, and conceptualize the role of social knowledge in precipitating institutional change.

Based on the above arguments, we develop an LRA framework to motivate two research questions for empirical analysis within the context of pharmaceutical industry sales professionals:

(1) How do organizations structure institutional work that allows organizational control of professionals they employ?

(2) How do changes in social knowledge influence interpretations of organizations' institutional work to precipitate institutional change?

Pharmaceutical sales professionals (PSPs) are well suited to our study aims. A majority of over 80,000 PSPs in the United States work in for-profit pharmaceutical companies who are obligated to optimize ROI for their stakeholders (Arnold, 2010). However, PSPs have been particularly successful in institutionalizing professionalization through: (1) formal associations that define the distinctive knowledge work that they perform (e.g. American Association of Pharmaceutical Sales Professionals or AAPSP); (2) accreditation and certification mechanisms that maintain and enforce standards and provide continuing education; and (3) explicit code of ethics (Clark et al., 2001). ${ }^{[1]}$ Several federal agencies, including the states of New Hampshire and Vermont, have certification standards for PSPs. However, despite professionalization successes, PSPs may be best viewed as emerging professionals, or neo professionals per von Nordenflycht (2010), since they lack power and autonomy in decision making and are historically dependent on their employers. No study has examined the organizational control of PSP work or the plurality of logics that characterizes such professionals. Moreover, while the institutional literature has examined several classical professions (e.g. physicians, lawyers), emerging professionals in areas ranging from consulting to customer-facing have been rarely studied.

Our paper is structured as follows. First, we conceptualize an LRA framework that bridges institutional and role theories. Specifically, we leverage the role theory concepts of role enactments and interpretations to ground the study's research questions. Subsequently, we present our research setting, methods for collecting multi-source data, and analytical procedures used. Thereafter, we outline the results and close with a discussion that links our results to the literature and identifies directions for future research.

\section{LRA FRAMEWORK}

In theorizing the link between institution and action, Barley and Tolbert (1997) drew from Giddens' (1976) notion of structuration and Goffman's (1983) conception of interaction to posit that scripts are 'tools' for structuring action that reflect the general principles of an institutional logic, just as speech (actions) draws from principles of 


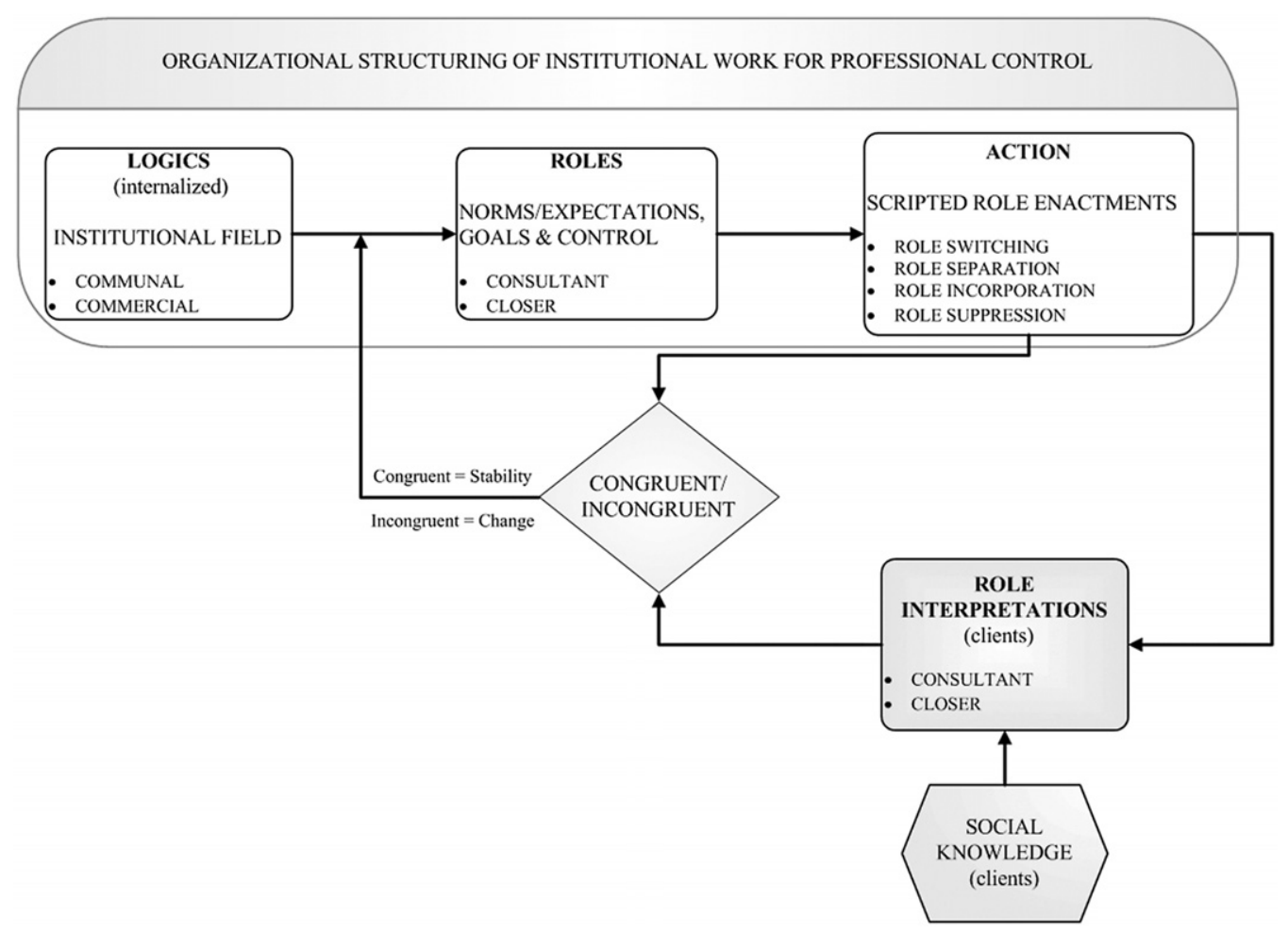

Figure 1. The Logics-Roles-Action (LRA) framework for organizational structuring of institutional work and its institutional change implications

grammar (institutions). We build on this foundation by proposing that scripts, conceived in the context of role theory, are instruments that organizations use to structure and institutionalize specific roles that serve as useful conduits of institutional work for bureaucratic control of professional work. This approach is consistent with institutional theorists who propose logics as common meaning systems that structure organizations in a particular field by providing frames for decision making (Caronna, 2004; Scott, 2001, p. 57; Thornton and Ocasio, 2008). Although original conceptions of logics adhered to isomorphism by theorizing a single dominant logic for organizational fields, institution bound professionals bring a plurality of logics to their organizational roles. How exactly these pluralistic logics are played out in everyday professional work, and how organizations manage professional work to achieve desired outcomes is the focus of our theoretical contribution.

Figure 1 depicts our theoretical framework that intersects three conceptual themes: (a) institutional foundations for communal and commercial logics that organizations internalize to control professional work (LOGICS); (b) institutionalization of consultant and closer roles that correspond to communal and commercial logics respectively (ROLES); and (c) strategies and tactics for directing professional work in accord with scripted role enactment plans that address the tension of pluralistic logics (ACTION). Also depicted in Figure 1 are role interpretations that clients attribute to professionals' role enactments. 
Table I. The Logics-Roles-Action framework: terminology and definitions

\begin{tabular}{|c|c|c|}
\hline \multirow[b]{2}{*}{ Constructs } & \multicolumn{2}{|c|}{ Role } \\
\hline & Closer & Consultant \\
\hline Definition & $\begin{array}{l}\text { Professionals are expected to use their } \\
\text { expertise to counter customer } \\
\text { objections, use persuasive influence } \\
\text { tactics and give priority to closing } \\
\text { the deal with maximal monetary } \\
\text { gains }\end{array}$ & $\begin{array}{l}\text { Professionals are expected to use their } \\
\text { expertise to understand and solve } \\
\text { customer problems, give priority to } \\
\text { customer needs, and act with } \\
\text { restrained opportunism }\end{array}$ \\
\hline $\begin{array}{l}\text { Related institutional } \\
\text { logic }\end{array}$ & $\begin{array}{l}\text { 'Commercial': meaning systems that } \\
\text { emphasize business values of } \\
\text { rationality, instrumentality, and } \\
\text { monetary gains (Haveman et al., } \\
2007 \text { ) }\end{array}$ & $\begin{array}{l}\text { 'Communal': meaning systems that } \\
\text { emphasize social trusteeship values } \\
\text { of expertise, morality, and } \\
\text { benevolence (Abbott, 1988; } \\
\text { Haveman and Rao, 1997) }\end{array}$ \\
\hline $\begin{array}{l}\text { Role enactment: } \\
\text { norms and } \\
\text { expectations }\end{array}$ & $\begin{array}{l}\text { Agents use their expertise to counter } \\
\text { customer objections, give priority to } \\
\text { closing the 'sale' with maximal } \\
\text { monetary gains to the organization, } \\
\text { and use persuasive influence tactics }\end{array}$ & $\begin{array}{l}\text { Agents use their expertise to } \\
\text { understand and solve customer } \\
\text { problems, give priority to customer } \\
\text { needs, and act with restrained } \\
\text { opportunism }\end{array}$ \\
\hline $\begin{array}{l}\text { Role enactment: } \\
\text { performance goals }\end{array}$ & $\begin{array}{l}\text { Achieve or exceed sales targets and } \\
\text { maximize organizational return on } \\
\text { profitability }\end{array}$ & $\begin{array}{l}\text { Build long term relationships with } \\
\text { target customers, and maximize } \\
\text { customer satisfaction }\end{array}$ \\
\hline $\begin{array}{l}\text { Role enactment: } \\
\text { control instruments }\end{array}$ & $\begin{array}{l}\text { Socialization, monitoring, and } \\
\text { compensation }\end{array}$ & $\begin{array}{l}\text { Socialization, monitoring, and } \\
\text { compensation }\end{array}$ \\
\hline Role interpretation & $\begin{array}{l}\text { Professional is categorized } \\
\text { unambiguously by observers and } \\
\text { clients as a commercial agent } \\
\text { motivated by financial gain }\end{array}$ & $\begin{array}{l}\text { Professional is categorized } \\
\text { unambiguously by observers and } \\
\text { clients as a consultative agent } \\
\text { motivated by serving client interests }\end{array}$ \\
\hline Social knowledge & $\begin{array}{l}\text { A coherent set of interpretable data } \\
\text { about others' intentions, desires, and } \\
\text { beliefs that individuals are motivated } \\
\text { to acquire, process, and store in } \\
\text { order to successfully navigate social } \\
\text { interactions and facilitate social } \\
\text { category judgments }\end{array}$ & $\begin{array}{l}\text { A coherent set of interpretable data } \\
\text { about others' intentions, desires, and } \\
\text { beliefs that individuals are motivated } \\
\text { to acquire, process, and store in } \\
\text { order to successfully navigate social } \\
\text { interactions and facilitate social } \\
\text { category judgments }\end{array}$ \\
\hline
\end{tabular}

Our framework posits that clients draw on their social knowledge to infer role interpretations permitting them to deviate from those intended by organizational role scripts and, when they do, incongruent role interpretations result. The framework identifies conditions under which clients' incongruent role interpretations disrupt the structures that legitimize the link between logics and roles, thereby problematizing organizational agency in institutional work. To aid development of the preceding themes, we summarize the key terminology and definitions in Table I, where roles are the organizing concepts with PSPs as the illustrative context. Nevertheless, the underlying ideas have broader application to institutional work in for-profit organizations. 


\section{Plurality of Institutional Logics in Professional Work}

Institutional logics are 'axial systems of meaning' for structuring social order and action (Dunn and Jones, 2010; Friedland and Alford, 1991; Suddaby, 2010, p. 16; Thornton and Ocasio, 2008). As per Thornton and Ocasio (1999), institutions, through their structural, normative and symbolic properties, support the production and reproduction of socially constructed and commonly shared beliefs and values that constitute its logics. In turn, logics act as shared templates for individual action that are rooted in deeply held, often unchallenged assumptions and beliefs (Barley and Kunda, 1992), that originate in societal institutions such as family and professions (Dunn and Jones, 2010). Thus, the concept of institutional logics refers to a meta-theory that focuses on the mechanisms that link individual roles (agency) at the micro-level and institutionalized practices and rule structures (meaning systems) at the macro-level.

Interdependent and contradictory logics are a feature of institutional fields where pluralistic logics with distinct meaning systems often conflict with each other by imposing inconsistent expectations (Nigam and Ocasio, 2010). Such pluralistic logics are pervasive in several industries ranging from publishing (market and craft logics; Thornton, 2002) to thrifts (moral and progressive logics; Haveman and Rao, 1997). We propose that institutional work in modern for-profit organizations is similarly characterized by a plurality of commercial and communal logics. We conceptualize commercial logics as meaning systems that emphasize business values consistent with shareholder responsibility including rationality, instrumentality, and monetary gains (Haveman et al., 2007); while communal logics are meaning systems that emphasize social trusteeship values consistent with fiduciary responsibility including expertise, morality, and benevolence (Abbott, 1988; Haveman and Rao, 1997). The roots of commercial and communal logics can be traced to Weber's (1978) formal and substantive rationality respectively. As per Weber, formal rationality involves decisions emphasizing cost-benefit calculations, whereas substantive rationality emphasizes principled values. Today, both logics are meaningful and legitimate values of a larger institutional field characteristic of a capitalist society inspired by organized activities for ethical and principled pursuit of profits (Davis et al., 1997).

Tensions between pluralistic logics are often not benign and become especially problematic when individuals or organizations are beholden to fiduciary responsibility as in the case of professionals. Such tensions have been studied in the evolution of thrift industry as a negotiation between communal and progressive ideals (Haveman and Rao, 1997; Haveman et al., 2007), in the Atlanta Symphony Orchestra as the contestation between the sacred and profane market logics (Glynn and Lounsbury, 2005), in the mutual fund industry as a competition between trusteeship and performance logics (Lounsbury, 2007), and in microfinance organizations as a challenge between the banking and development logics (Battilana and Dorado, 2010). Additionally, tension between communal and commercial logics have been studied by entrepreneurship (Blatt, 2009; communal/contracting schemas) and marketing scholars (Aggarwal and Law, 2005; communal/exchange norms).

Past research suggests that the temporal unfolding of the tension between the pluralistic logics in organizational settings may evidence at least three modal patterns. First, 
taking a macro perspective, studies emphasize an inherent incompatibility between logics such that a competitive pattern is evident where one of the logics eventually wins, forcing the field to coalesce around a new dominant logic (Greenwood and Suddaby, 2006; Lounsbury, 2002; Nigam and Ocasio, 2010; Rao et al., 2003; Thornton, 2002).

Second, adopting a micro perspective, studies emphasize modalities of mutual coexistence of pluralistic logics such that organizational actors creatively draw upon or shift between identities rooted in the different logics to suit their interests and inclinations (Battilana and Dorado, 2010; Dunn and Jones, 2010; Marquis and Lounsbury, 2007; Purdy and Gray, 2009). For instance, Jones and Livne-Tarandach (2008) document architects' rhetorical strategies where architects creatively draw on keywords and vocabularies of multiple logics, while Meyer and Hammerschmid (2006) illuminate how actors creatively translate global logics into local versions and in the process deliberately manipulate competing logics to their advantage (Suddaby and Greenwood, 2005). In a similar vein, Cooper et al. (1996) show how emergent managerial logics overlay on pre-existing professional logics in law firms allowing actors to construct varying interpretive schemas which in turn promote organizational change.

Third, adopting an organizational perspective, studies emphasize patterns of structured coordination such that the pluralistic logics coexist like the second perspective but organizational agency is highlighted in structuring coordinating mechanisms for navigating the latent conflict of pluralistic logics (Glynn, 2008; Kraatz and Block, 2008; Lounsbury, 2007; Pratt and Kraatz, 2009; Reay and Hinings, 2009). This perspective parallels the professionalism as a 'resource' view in the sociology of professions literature (Alvesson and Johansson, 2002). As per this view, managers internalize professionalism 'from above' to gain external legitimacy while asserting internal authority to motivate, direct, and regulate professionals to achieve organizational objectives (Evetts, 2011, p. 408). This body of work points to the growth of organized systems that intricately weave commercial practices and professional priorities, and to organizations as increasingly the primary agent of control over professional work (Brock, 2006; Faulconbridge and Muzio, 2008; Kipping, 2011).

Building on the third perspective, the LRA framework proposes that organizations actively internalize the conflicting features of pluralistic logics by institutionalizing roles to act as instruments for directing professional action to serve organizational goals. Specifically, the LRA framework views for-profit organizations as active and creative arbiters of pluralistic logics that define professional work rather than as reactive institutions burdened to cope with the conflict that professionals bring to their commercial logics. Our internalization argument is distinct from sedimentation which draws on the geological metaphor of one institutional logic layered on top of another (Cooper et al., 1996). Active internalization of pluralistic logics asserts and assures the coexistence of both logics, and focuses attention on structures for using this pluralism as a resource to scaffold goal-directed action. Pharmaceutical companies exemplify this active internalization of pluralistic logics. Company mission statements emphasize commercial goals while concurrently highlighting pursuit of communal goals. For instance, the Novartis company mission statement states: 
We want to discover, develop and successfully market innovative products to prevent and cure diseases, to ease suffering and to enhance the quality of life. We also want to provide a shareholder return that reflects outstanding performance and to adequately reward those who invest ideas and work in our company. (Novartis, 2012; emphasis in original)

The two statements in the mission statement above align closely with the communal and commercial logics, respectively. Such pluralistic emphasis is common among leading, publicly held pharmaceutical companies. Internalization of pluralistic logics allows organizations to structure mechanisms for managing professional work by institutionalization of roles, which we address next.

\section{Institutionalization of Roles for Organizational Control of Professional Work}

Role theory proposes roles to be a relatively unique cluster of expectations and norms that are typically diagnostic of a particular socially defined category. Behavioural routines that provide recipes for action in order to conform to a social category are referred to as role scripts (Stryker and Statham, 1985). Although they did not refer to role theory, Barley and Tolbert $(1997$, p. 98) assert that institutions are enacted by [role] scripts, which they defined as 'observable, recurrent activities and patterns of interaction [that are] characteristic of a particular setting'.

Consistent with Barley and Tolbert, we posit that organizations structure norms, expectations, and goals (Ryals and Davies, 2010; Weitz and Bradford, 1999) associated with two distinct roles - closer and consultant - that reaffirm and reproduce the institutional routines of commercial and communal logics respectively. The institutionalization process involves setting norms, expectations, and goals as part of organizational structures (e.g. job descriptions) and controls (e.g. socialization, monitoring). In a closer role, organizational agents are expected to use their expertise to counter customer objections, use persuasive influence tactics, and give priority to closing the deal with maximal monetary gains (see Table I). For instance, in the case of the pharmaceutical industry, PSPs are socialized into closer role scripts that include detailing (e.g. presentations to physicians to promote company products) and sampling practices (e.g. inducing trial through free samples). Consistent with closer role expectations, organizations set performance goals that focus the agents' attention on sales targets, profitability, and/or return on investment.

In a consultant role, organizational agents are expected to use their expertise to understand and solve customer problems, give priority to customer needs, and act with restrained opportunism (see Table I). For instance, organizations may direct PSPs to enact a consultant role by updating physicians with current research even if the results are unfavourable for the company's drugs, and provide customized information to physicians based on their attitudes towards prescribing (Elling et al., 2002). Moreover, to focus and direct PSP action towards a consultant role, organizations may set related performance goals that include building long-term relationships and maximizing client (physician) satisfaction. 
To ensure that employed professionals enact organizationally arbitrated roles, firms typically use socialization, training, and compensation as mechanisms of role control (Anderson and Oliver, 1987). Socialization and training promote process control by facilitating adoption and assimilation of organizationally mediated norms, expectations, and goals. For instance, Greene (2004) suggests that training and socialization programmes condition PSPs to internalize a closer persona even while enacting professionally intensive exchanges with physicians. Such conditioning is replete with artefacts and scripts including interaction etiquette, dress code, grooming, use of language, and even how they should hold their pens, while showing scientific materials to physicians (Greene, 2004). Firms utilize compensation plans for outcome control to protect them from moral hazard of autonomous agents. For instance, to support a closer role, a significant portion of PSP compensation, ranging from 25 to 40 per cent, is linked to achievement of sales targets, with additional incentives used to motivate PSPs' efforts towards sales goals (Arnold, 2010). Likewise, to ensure compliance of employed professionals with a consultant role, organizations tie PSP bonus and incentives to client satisfaction, and rely on process controls that focus on quality of PSP interactions with clients. Together, closer and communal roles are powerful instruments for embedding action at the micro-level in deeply rooted logics at the macro-level (e.g. institutional).

\section{Action as Professional Role Enactment}

A significant challenge for organizations is to control professional role enactments or actions that mitigate the potential conflict in the plurality of consultant and closer roles. Conflict may surface because upholding communal interests often is at odds with maximizing commercial gains. When contradictory roles are enacted, role interpretations are likely to be confounded, blurred, miscoded, or misinterpreted. ${ }^{[2]}$

Organizational success is vested in professional action that cues unambiguous interpretations among its clients and minimizes errors of miscoding role enactments. For instance, when a PSP is directed to provide a physician with recent medical knowledge that is not particularly favourable towards the company's products, the organizational goal is to cue physicians to a consultant role and unambiguously rule out a closer role, thereby clarifying the social category enacted. For this reason, employed professionals are rarely left to devise their own role enactments. Rather, role enactment is a strategic prerogative for most organizations. Organizations use past experiences, exemplars (e.g. highly successful employees), research (e.g. persuasion), and feedback (e.g. from clients) to strategize role enactment plans for employed professionals which are often fine-tuned and updated as more knowledge is gained from the field (Greene, 2004). Such scripting of role enactment usually includes an overall strategic objective and specific tactics for engaging observers (e.g. clients) to generate the intended role interpretations.

Through concepts such as role switching, separation, incorporation, and suppression, role theory provides a framework for conceiving role enactments to navigate the conflicted action implications of pluralistic roles (Ashforth, 2001; Settles et al., 2002). Role switching involves organizational strategies and tactics for carefully scripting the points of transition for switching from consultant to closer role enactments within an exchange encounter and vice versa so that clients are cued by switches to avoid ambiguous role 
interpretations (Ashforth, 2001). Role separation, by contrast, involves temporally separating consultant and closer role enactments (or vice versa). That is, in any given continuous interaction with the client, employed professionals are directed to enact a singular role routine resulting in unambiguous role interpretations. Role incorporation is an organizational strategy that acknowledges the tension between roles and uses it to develop scripts for innovative enactments that integrate both roles (Settles et al., 2002). Finally, role suppression involves a strategy wherein employed professionals are scripted to purposely enact role routines that not only emphasize a particular role but also negate the potentially conflicted role. An example noted earlier involving PSPs purposely providing credible information to physicians that may be detrimental to commercial interest illustrates a script that strategically directs PSPs to enact a consultant role while suppressing inferences related to a closer role.

In summary, the LRA framework posits that organizations institutionalize roles corresponding to the internalized logics and script role enactments to use them as instruments for directing professional action in the service of organizational goals. Because organizations situate roles within widely accepted logics of their institutional fields, and scaffold the roles to enact goal-oriented action, we refer to such organizational efforts as institutional work. No empirical study to date has explored or examined how organizations in practice situate and scaffold roles to control professional work.

Research Question 1: How do organizations structure institutional work that allows organizational control of professionals they employ?

\section{Social Knowledge and Institutional Change Dynamics}

Intended roles in professional enactments are rarely isomorphic with roles interpreted by clients. As noted, organizations structure role enactments as institutional work to induce inferences of a particular role category (e.g. consultant). Role interpretations are clients' actual categorization of actors' role enactments based not only on the displayed cues but also on underlying motivations that are inferred usually via attributional processes (Howard, 1985). These attributional processes engage clients' social knowledge (to be discussed) and information about the situation that goes beyond the cues from specific role enactment (see Table I). Thus, a consultant role enactment that cues deliberate suppression of commercial interest may be inferred as a closer role instead if the client has social knowledge indicating that the employed professional's motivations are suspect or untrustworthy. When this occurs, clients are likely to reject the intentional cues encoded in role enactments.

The organizational imperative is to minimize gaps between role enactments and role interpretations. Gaps are minimized when role enactments are rooted in scripts that are drawn from widely shared institutional logics and display behavioural and nonbehavioural cues for unambiguous role interpretations. Thus, organizations deliberately leverage logics that are clearly understood and deeply grounded in the larger institutional field to script role enactments that reproduce and reaffirm these logics. Directing professional work to constitute a new institutional order or experiment with role enactments 
injects uncertainty in goal pursuit (e.g. ambiguous inferences) and risks effectiveness (e.g. profitability).

Despite the wilful and strenuous efforts of organizations, intended role enactments and role interpretations diverge. We posit that clients' social knowledge is relevant for understanding whether intended role enactments and interpretations will converge or diverge. Rooted in the theory of mind (Perner, 1999; Premack and Woodruff, 1978) or folk psychology (Lillard, 1997), social knowledge is defined as a coherent set of interpretable data about others' intentions, desires, and beliefs that individuals are motivated to acquire, process, and store in order to successfully navigate social interactions and facilitate social category judgments (Frith and Frith, 2012; Lillard, 1997). Individuals construct such knowledge through attributional processes of reasoning, categorizing, and learning (Bruner, 1990; Wellman, 1993) as they observe and reflect on social interactions as well as learn from others' knowledge of social interactions (Arrow, 1994). Viewing role enactments as social interactions, we posit that clients are motivated to acquire social knowledge to categorize professional role (e.g. consultant or closer) and to facilitate interpretation using information gleaned during the interaction (e.g. accept or reject). To the extent that clients are professionally organized to share and construct collective knowledge (e.g. physicians in the American Medical Association), they are likely to construct their social knowledge more so on the widely shared collective beliefs than on directly cued information in individual interactions with professionals. Moreover, because client (e.g. physician) interactions with the pharmaceutical industry are of broad public (e.g. patient) interest, the ebbs and flows of discourse on industry practices in publicly available media (e.g. newspapers, TV, magazines) also shape the emergent social knowledge shared among clients. In a sense, social knowledge is continuously recalibrated, refined and, if needed, revised as clients engage in collective processes to share and construct this knowledge based on their myriad individual experiences and informed by the unfolding discourse in the public media. Because clients' social knowledge is constructed largely outside organizational influence and for this reason more useful in interpreting clients' individual interactions with PSPs, cues from specific role enactments by professionals hold relatively less sway on clients' social knowledge or in evoking desired role categories.

Specifically, clients' social knowledge that confirms the authenticity of role enactments (i.e. role congruency) will likely bolster clients' confidence in interpreting and categorizing role cues to minimize gaps. By contrast, social knowledge that contradicts the authenticity of role enactments (i.e. role incongruency) will likely disconfirm clients' (earlier) role interpretations and prompt reinterpretation and re-categorization to widen gaps. Institutional change is triggered when reinterpretations and re-categorizations become widely shared and gaps become irreconcilable.

We posit that institutional work by organizations structured through role enactments of PSPs may, under role incongruent conditions, precipitate unintentional institutional change. Lawrence et al. (2009, p. 11) note that institutional work may fail to affect intended change, or might disrupt institutional structures in ways that are 'very different from those originally conceived by the [organizations] involved'. Employed professionals may unwittingly enact roles as naïve institutional agents without fully grasping the institutional effects of their collective actions (Scott, 2008). Although past research has 
discussed such possibilities (Kraatz and Block, 2008), no study to our knowledge has examined conditions that mediate the relationship between the institutional work and changes in institutional structures. We posit that widespread shifts in social knowledge are a relevant factor in precipitating change in institutional structures.

Research Question 2: How do changes in social knowledge influence interpretations of organizations' institutional work to precipitate institutional change?

\section{STUDY DESIGN}

We used a case-based design involving in-depth, interpretive analysis of organizational strategies and tactics utilized to control professional work (as per Research Question 1). In addition, we tracked and analysed public documents to assess changes in social knowledge and its influence in shifting clients' role interpretations and precipitating institutional change (as per Research Question 2). The specific case selected allowed access to materials that illuminate an organization's strategy-in-action consistent with the practice approach to institutions (Jarzabkowski et al., 2009). A practice approach, as advocated by Kraatz and Block (2008) and Jarzabkowski et al. (2009): (a) focuses attention on the everyday actions of actors, thereby emphasizing role enactments; (b) studies actions from a praxis lens, thereby embedding action within institutional logics; and (c) acknowledges the tensions of institutional pluralism, thereby attending to navigation of pluralistic logics. Below, we outline the: (1) case study selection; (2) coding and categorizing of organizational strategies and tactics; and (3) tracking and analysing changes in social knowledge and institutional structures.

\section{Selection of Case Study}

In order to explore the research questions, we required unfettered access to internal organizational documents and senior management personnel to understand strategies and tactics used in practice to control professional work. However, these materials are proprietary data that are rarely accessible. A source of reliable and valid data is discovery documents generated during the pre-trial (discovery) phase in a lawsuit in which each party assembles evidence for litigation by requesting and acquiring pertinent documents and other relevant information, including access to executives (e.g. for deposition). The laws governing public access to court records provide detailed, authenticated, and otherwise proprietary data for review and analysis. Court records are a rich source of data as they include authenticated internal organizational documents, sworn testimonies, accounting and billing statements, reports from consultants and suppliers, and other related materials. Often sworn testimonies probe the thinking underlying actions, just as records of strategy meetings outline the rationale and goals underlying proposed initiatives. However, court documents do not constitute a complete record of either the motivations behind organizational strategies, or actions that could have been observed. Nevertheless, court documents are relatively superior to other practical approaches in terms of the quality and quantity of obtained data. Increasingly, recent research has used 
court documents to obtain insights into pharmaceutical marketing practices (Healy and Cattell, 2003; Psaty and Kronmal, 2008; Ross et al., 2008).

To identify an appropriate case study, we examined six major litigation cases adjudicated since 2003 that involved PSPs employed in the pharmaceutical industry. We preferred a case that: (1) provided rich content and relatively comprehensive coverage of organizational strategies and tactics for managing professional work; (2) involved a major drug (e.g. blockbuster) of a leading pharmaceutical company (e.g. Fortune 500) so that the obtained insights would reflect industry practices; and (3) offered high degree of accessibility such that most, if not all, of the relevant discovery documents could be obtained for original analysis. Based on these considerations, we selected United States of America ex. rel David Franklin vs. Pfizer Inc, and Parke-Davis, Division of Warner-Lambert Company. The case involved marketing practices related to Neurontin ${ }^{\mathbb{B}}$ (chemically known as gabapentin). The US Food and Drug Administration (FDA) initially approved Neurontin in 1993 for adjunctive treatment of partial complex seizures in adults older than 12 years in age and for dosages not exceeding $1200 \mathrm{mg} /$ day. By the mid-1990s, Neurontin experienced its highest growth as treatment for off-label uses of pain syndromes (e.g. neuropathic pain) and psychiatric disorders (e.g. bipolar disorders). Off-label uses involved uses not specified in the labelling approved by the FDA but approved by a licensed physician on the strength of medical judgment. At its peak, Neurontin was marketed in over 100 countries, used by over 12 million patients, and was generating annual revenue of over $\$ 2.7$ billion. The case was settled on 13 May 2004, and Pfizer was directed to pay $\$ 430$ million in settlement fees and make fundamental changes to its marketing practices for violating the Food, Drug and Cosmetic Act.

\section{Coding and Categorizing Organizational Strategies and Tactics}

The court documents were obtained by the researchers directly from the attorneys, and supplemented by digital archival documents from the University of California, San Francisco website (http://dida.library.ucsf.edu). We had access to over 5,000 pages of court discovery documents. Two teams, each involving a lead researcher and a student, were constituted. Both teams worked independently to comb the materials to extract the key strategies and tactics for managing PSP work, and met subsequently to resolve differences and integrate extracted strategies and tactics. Tactics were grouped under strategies based on team judgments, and between team correspondence initially focused on strategies and then moved on to tactics. Discovery documents and supplementary exhibits were treated as textual data to be interpreted through a series of part to whole iterations involving distinct stages of intra- (within strategies, placing focus on tactics) and inter-strategy analysis (between strategies, placing focus on objectives). Moreover, we followed an iterative process by challenging emergent concepts from inter-strategy analysis through another round of intra-strategy analysis, and refining the concepts through a return to inter-strategy analysis. During each step, emergent concepts were reviewed for consistency with the definition of consultant and closer roles. Triangulation across the teams ensured that marginal and less relevant role concepts were ruled out. The results were tabulated for each strategy and a table developed to display strategy-tactics linkages. 


\section{Tracking and Analysing Changes in Social Knowledge and Institutional Structures}

We recognize that causal basis of change is difficult to establish in a case study and alternative explanations are hard to rule out. As such, we do not claim to provide irrefutable evidence of causality between institutional work and institutional change. Rather, our analytical approach provides initial insight into institutional changes that may be traced to institutional work rooted in organizational strategies and tactics.

We tracked and analysed changes in social knowledge related to organizational strategies and tactics as represented in public and medical materials (e.g. publications, journals). Three data sources were utilized to assess changes in social knowledge: (1) public disclosures involving PSP work following the court case; (2) public disclosures of similar strategies and tactics by other organizations in the industry; and (3) reports of strategies and tactics by pharmaceutical companies in leading medical journals, by searching the PubMed database from the US National Library of Medicine (i.e. Fournal of the American Medical Association and New England Fournal of Medicine). We reviewed articles published subsequent to the court settlement (13 May 2004) in the popular press such as Nerw York Times, Wall Street Fournal, and National Public Radio.

Finally, we tracked and analysed changes in institutional structures related to PSP work practices. Specifically, we tracked public materials as noted above but analysed them with a focus on: (1) physician interpretations of PSP role and/or changes in practices governing physician-PSP interactions; (2) regulatory changes influencing PSP actions related to strategies and tactics identified above; and (3) changing public perceptions of the PSP role that can be traced to the specific strategies and tactics identified, and/or the court case discussed.

For both analyses, we followed an approach similar to that used for the first research question with two teams independently analysing materials and meeting subsequently to identify convergent results and discuss divergences. The results were summarized as a narrative and institutional changes linked to individual strategies identified as per our focus.

\section{FINDINGS}

\section{Research Question 1: Strategies and Tactics as Scripted Role Enactments}

Our analysis identified four distinct strategies, each with a coherent set of tactics, to script role enactment of sales professionals: (1) evidence-based strategy related to production of scientific evidence and its dissemination by sales professionals; (2) medical education strategy related to continuing education of physicians about emergent standards of medical care and its facilitation by sales professionals; (3) surrogate selling strategy related to sales professionals' recruitment of physicians for peer-to-peer selling; and (4) market penetration strategy related to sales professionals' efforts to identify and target physicians who offer high-return from prescriptions. Table II summarizes the objectives established for each strategy, as well as the specific tactics used to implement each strategy. Verbatim comments are included from internal documents and sworn testimonies. References to specific exhibits are provided in the text, but not individually listed in the bibliography to 


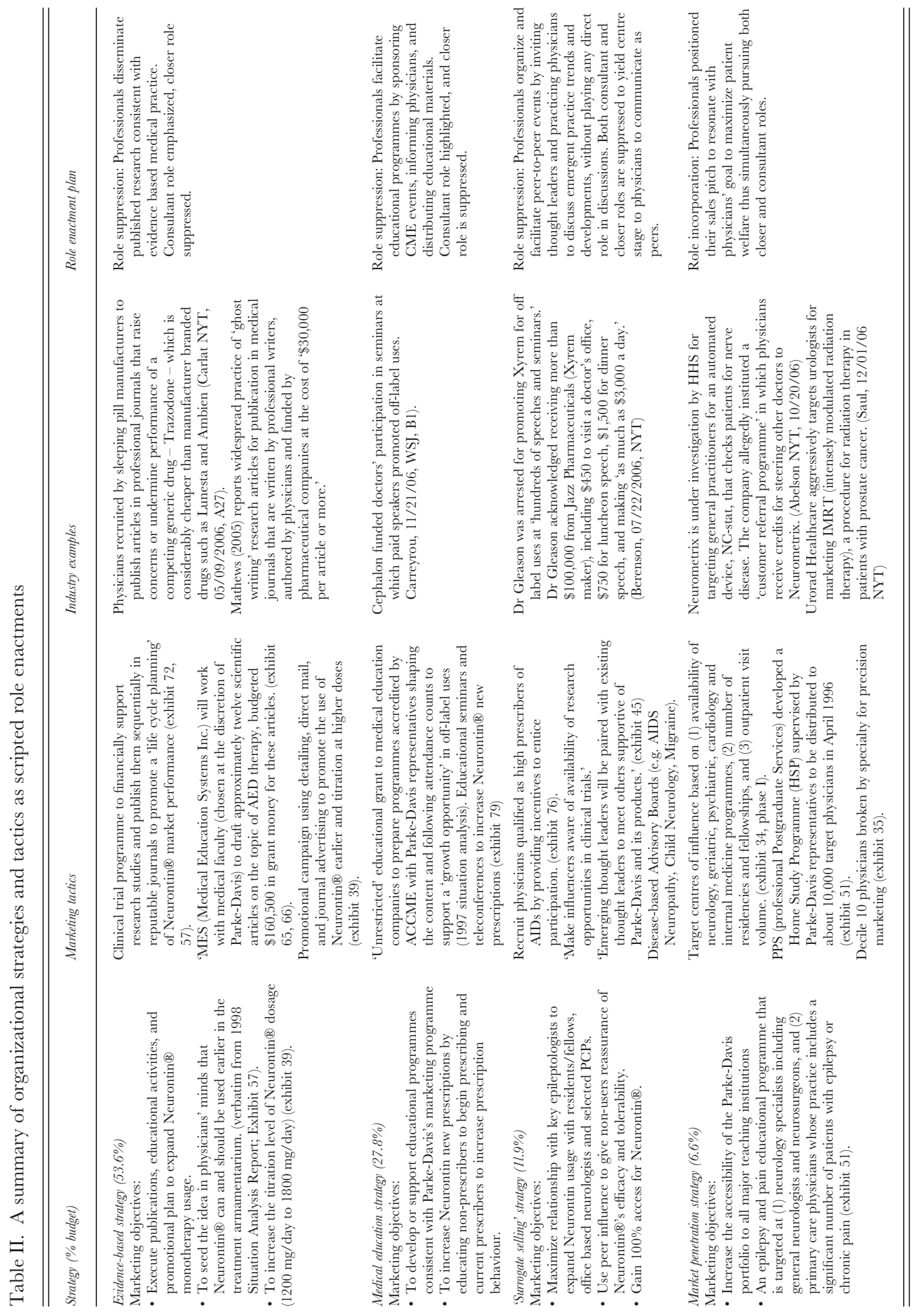


avoid repetitive reference to the same source. Table II also includes industry examples indicating the corresponding strategy's prevalence in the industry.

Evidence-based strategy. As noted in Table II, evidence-based strategy had three objectives: (a) to expand Neurontin monotherapy usage (exhibit 77); ${ }^{[3]}$ (b) to encourage Neurontin use earlier in the treatment regime; and (c) to increase the titration level by 50 per cent from $1200 \mathrm{mg} /$ day to $1800 \mathrm{mg} /$ day. Internal documents state that the evidence-based strategy was motivated by commercial goals to increase sales (exhibit 21), and return on investment estimates were explicitly calculated to target disease indications with the greatest revenue potential. Parke-Davis estimated that the evidence-based strategy could generate $\$ 204$ million a year in off-label sales before the patent expired (exhibit 29).

In general, the tactics involved a coordinated programme of targeted research studies for sequential publication in peer-reviewed journals (exhibits 72, 77, 57). This included: (a) covert activities including engaging outside commercial companies; and (b) overt activities that directed PSP to disseminate the evidence generated from covert activities. For instance, PSPs covertly invited key physicians to participate in clinical trials to investigate the efficacy of Neurontin under different conditions (e.g. higher titration, early use). The participating physicians released the data from funded clinical trials to contract companies for statistical analysis and manuscript development. Internal documents show that Parke-Davis contracted with Medical Education Systems Inc. (MES) to draft and facilitate publication of 12 articles with a budget of $\$ 165,000$ in peer-reviewed journals. MES invited each participating physician to be a co-author or a lead author on the publication, a practice that became known as guest- or ghost-authorship (Ross et al., 2008). Typically, the published articles did not disclose the company's involvement in generating and publishing the evidence.

Once the articles were published, PSPs' role enactments involved overt activities that disseminated the published work broadly to physicians. Not being privy to the commercial intent in evidence generation, physicians were probably cued to a consultant role by PSPs' interest in providing evidence-based medical knowledge, while negating any intent to 'close' sales for their drugs. Thus, this strategy is consistent with a role suppression enactment plan.

Medical education strategy. The company conceived the medical education strategy with two aims: (1) to develop and support educational programmes that discuss unapproved uses of Neurontin, and allow continuing medical education (CME) credits to participating physicians; and (2) to increase Neurontin new prescriptions by educating nonprescribers to begin prescribing and current prescribers to increase prescription behaviour (exhibit 34). The company allocated 27.8 per cent of its marketing budget to this strategy (second row, Table II).

Tactics associated with this strategy included unrestricted educational grants to medical education companies (exhibit 79). Technically, unrestricted grants required Parke-Davis to relinquish control over programme speakers and content to allow continuing medical education credit to participating physicians (as per the Accreditation Council of Continuing Medical Education or ACCME). Although Parke-Davis indicated compliance with ACCME guidelines, internal documents show that sales professionals 
provided input to conference content, suggested speakers, and tracked participating physicians' pre- and post-seminar prescribing behaviour to examine the commercial effectiveness of educational grants (exhibit 79). The PSPs' role included identifying physicians for participation in speakers' bureau, and facilitating sponsored educational events. In some instances, Parke-Davis paid physicians to attend seminars, act as part of the audience, and plant leading questions intended to portray Neurontin in a positive light (e.g. \$200 honorarium, exhibit 79).

Tactics associated with the medical education strategy were generally not transparent to participating physicians, even those who were paid by Parke-Davis. Without full knowledge of Parke-Davis's strategy and tactics, participating physicians likely viewed PSP role enactments as motivated mainly by supporting the dissemination of emergent medical knowledge, and facilitating earning of CME credits. Most physicians had no knowledge that their prescription behaviour was tracked following participation in an educational programme to estimate commercial payoffs. Thus, consistent with a role suppression plan, physicians' role interpretations cued a consultant role by PSPs' facilitation of physicians' continuing education with little interest in extracting commercial benefits per the closer role.

Surrogate selling strategy. As noted in Table II, this strategy had three objectives: (a) build and harvest relationships with key epileptologists to expand Neurontin usage and penetration (exhibit 45); (b) rely on peer influence to assure non-users about Neurontin's efficacy and tolerability; and (c) gain 100 per cent access for Neurontin. This strategy relied on physicians as surrogates for PSPs to sell Neurontin to their peers.

In particular, the tactics focused on building a network of key epileptologists called 'Neurontin ${ }^{\circledR}$ Champions' who can be influential in promoting Neurontin use. Sales professionals identified, recruited, and where necessary, enticed thought leaders from large teaching hospitals to join an exclusive group of Neurontin champions. Court documents revealed that the enrolled Neurontin champions participated in speakers' bureau and physician-to-physician interactions ostensibly to promote Neurontin (exhibits 25, 26, 28, 38). PSPs were encouraged to 'expand the speaker base - identify and train strong Neurontin advocates and users to speak locally for Neurontin' (exhibit 19). To engage and compensate Neurontin champions for their time and effort, financial awards were provided in the form of direct payments, research grants, and/or support (exhibits 34, 61, 72). The company also organized disease-based advisory boards for discussing diagnostic criteria and appropriate treatment plans for specific diseases (e.g. neuropathy, migraine).

The premise of surrogate selling is that physicians neither attribute commercial intent to recommendations from trusted peers, nor do they suspect company complicity in the professional bonds among physicians. Both the Neurontin Champions and the company refrained from disclosing the associated financial awards, ensuring that surrogate selling was perceived as peer-to-peer communication untainted by company or commercial interest and, with PSPs remaining in the background, suppressed PSPs closer and consultant roles.

Market penetration strategy. This strategy aimed to penetrate the market for Neurontin by identifying and targeting 'high-value' physicians located in major teaching hospitals (see 
last row, Table II). For instance, Parke-Davis targeted neurology specialists and primary care physicians who have access to a significant number of patients suffering from chronic pain, and act as key gatekeepers for facilitating Neurontin use among patients. In addition, by focusing on major teaching hospitals, this strategy targeted physicians who had significant influence on practices adopted by other hospitals.

Tactically, sales professionals categorized physicians based on their potential for writing prescriptions for Neurontin into deciles, and identified the physicians in the top deciles for targeting (e.g. market potential of 10th decile physicians estimated at \$309,517, exhibit 35). Several tactics were devised to guide PSP role enactments for effective targeting. Specifically, for over 10,000 targeted physicians, PSPs facilitated a Home Study Programme that included focus on pain management. PSPs recruited and encouraged targeted physicians to join the programme. Parke-Davis invited senior PSPs to participate as observers in psychiatry teleconferences organized through a third party vendor (exhibit 37). Parke-Davis followed prescribing habits of targeted physicians, and directed PSPs to implement a retention programme for high-valued prescribers with expensive vacations and gifts.

Although the sales professionals were explicitly directed to enact a closer role in physician interactions, market penetration strategy incorporated a consultant role within a closer role. Instead of pushing drugs through a sales pitch, Parke-Davis directed PSPs to engage physicians by emphasizing advancements in pain management for patients suffering from epilepsy or other neurological conditions associated with chronic pain. Consistent with a consultant role, sales professionals were encouraged to gain expertise in pain management therapies and were called 'medical liaison officers' to signal that they are dedicated to providing medical information rather than promoting drugs. Thus, Parke-Davis apparently utilized a role incorporation strategy by concurrently emphasizing the closer and the consultant role.

\section{Research Question 2: Managed Professional Work and Institutional Ghange}

Changes in social knowledge. The selected case was unique in many respects. It represented: (a) one of the largest settlements for a federal case not involving the Department of Justice; (b) expanded jurisdiction of the False Claims Act to include marketing claims as criminal violations of federal and state laws; (c) revelations of complicity of several renowned physicians; and (d) evidence of substantial adulteration of medical literature by articles generated by undisclosed consultants retained by pharmaceutical companies (Steinman et al., 2006). The whistleblower in the case, David Franklin, was a medical liaison officer in the company and played an active role in public dissemination of industry marketing practices (Angell, 2005). The significant settlement amounts, \$240 million criminal fine plus $\$ 152$ million payments to healthcare programmes, drew widespread attention.

As a result, the Neurontin case entered and shifted the social discourse on pharmaceutical marketing and roles PSPs play in physician interactions. The outrage at scripted PSP role enactments was so pervasive and compelling that it resulted in several dedicated 
Wikipedia pages, a CBS '60 minutes' feature story, wide coverage in popular TV programmes such as $M S \mathcal{N} B C$, and an unprecedented interest among leading media such as Business Week, Newsweek, and PBS Front line.

Changes to social knowledge were bolstered by a series of reports confirming similar practices by other pharmaceutical companies, suggesting that these practices were not unusual but business as usual. Table II summarizes several reports that we culled from our analysis (see column 3). For instance, Mathews (2005) reported that guest- (or ghost)-writing to support evidence-based strategy was a widespread industry practice, and Carlat (2006) documented a concerted orchestration of publications by sleeping pill manufacturers to undermine generic substitutes. Likewise, in a detailed contribution to New York Times (titled Side Effects from a movie released in 2005), Berenson (2006) used the public arrest of Dr Peter Gleason, a well known Maryland psychiatrist for promoting Xyrem, to document the common industry practice of retaining leading practitioners with significant payments for surrogate selling. Several reports appeared subsequently to substantiate the funding of physicians to gain their participation in educational seminars with promotional intent (Carreyrou, 2006), and elaborate targeting programmes that provided credits to physicians for referring and steering other physicians towards companies' drugs (Abelson, 2006).

The diffusion of the preceding reports and analyses was accelerated by a number of social network sites. For instance, ProPublica, an independent, non-profit newsroom, collaborated with NPR, the Boston Globe, the Chicago Tribune, PBS Nightly Business Report, and Consumer Reports to systematically investigate and report how pharmaceutical company payments to physicians influence prescription practices. The publicity generated whetted the public's appetite for more thorough accounts of the pharmaceutical industry's influence on physician decisions. Several books were published to fill this need (Angell, 2005; Murray, 2010; Petersen, 2008), and turned up the heat on the organizational dilution of professional standards to promote commercial interests.

Overall, the change in social knowledge of pharmaceutical strategies and tactics triggered by the Neurontin case was so significant and profound that some scholars refer to it as the 'Neurontin legacy' (Landefeld and Steinman, 2009). Likewise, critical studies of ethics in pharmaceutical sales and the controversial role of PSPs are often dated by the Neurontin case (Datamonitor, 2006). Subsequent cases with significant settlement amounts involving Merck (2004, Vioxx), GlaxoSmithKline (2008, Paxil), and Eli Lilly (2009, Zyprexa) further solidified the emergent social knowledge.

Changes in institutional structures. Our analysis reveals significant changes in the normative, regulative, and cognitive institutional structures governing $\mathrm{PSP}$-physician interactions that can be traced to the changes in the social knowledge. For instance, in response to widespread disclosure of evidence-based strategy, the foumal of the American Medical Association, along with the International Committee of Medical Journal Editors revised its norms and procedures requiring all authors to include an explicit disclosure of conflicts of interest and, for industry sponsored research, to confirm independent statistical analysis as a condition for publication (Flanagin et al., 2006). Similarly, disclosures of medical education strategy prompted PhRMA, the trade group representing the pharmaceutical research and manufacturers of America, to revise its codes of conduct to prohibit 
industry involvement in CME programmes through educational grants. Likewise, several academic physician associations came out with new guidelines that prohibited pharmaceutical industry sponsorship of CME programmes.

In response to surrogate selling strategy, five states ${ }^{[4]}$ and the District of Columbia enacted laws that mandated pharmaceutical companies to file broad and unrestricted disclosure of payments to individual physicians, allowing such physicians to be publicly identified. Eleven additional states have proposed similar legislation. Prompted by legislative action and doubts about their authenticity, some companies now provide public access to their financial disclosure report (e.g. pfizer.com/responsibility/), enabling patients to search for payments received by individual physicians. Prosecutors have successfully evoked anti-kickback statute and the False Claims Act to prosecute cases involving financial arrangements between physicians and pharmaceutical companies.

Finally, the market penetration strategy prompted stringent federal regulatory oversight including the recent Physician Payments Sunshine provisions in healthcare reform legislation. These provisions require drug and medical device manufacturers to publicly report gifts and payments made to physicians. ${ }^{[5]}$ In addition, the American Medical Association code of conduct discourages doctors from accepting gifts from PSPs, and limits the total annual value of gifts to $\$ 100$. Wisconsin, Vermont, and Massachusetts have enacted laws against gift giving to physicians. Since the industry's market penetration efforts are rooted in tracking prescription data of individual physicians, the American Medical Association created the Prescribing Data Restriction Program to curb industry use of prescription writing data. Interested physicians can request that their prescribing data be withheld from pharmaceutical companies. Going still further, academic medical centres including Yale, Harvard, Duke, Stanford, University of Pennsylvania, Henry Ford Health System, and UCLA have banned physicians from receiving monetary or non-monetary gifts, and expressly prohibited PSPs from patient care areas (Croasdale, 2006).

\section{DISGUSSION}

In the spirit of Barley and Tolbert's (1997) conception that linking action and institutions allows understanding institutionalization as a dynamic, interdependent process, this study theorizes linkages among institutional logics, structured role scripts and professional action - the LRA framework - that makes three contributions to past research: (1) integrate institutional and role theories to understand how organizations structure institutional work to manage professional work; (2) examine the organizational strategies and tactics scripted as complex role enactment plans that constitute institutional work; (3) examine the evolution of clients' social knowledge that precipitates changes in institutional structures that is unintended by organizations' institutional work. Past research has examined organizational control of professional work in the traditions of structured coordination and professionalism as resource perspectives. Our study advances these perspectives by providing a rich and novel framework that intersects the concepts of pluralistic logics from institutional theory with pivots of role enactments from role theory to theorize how organizations structure institutional work. Suddaby et al. (2009) alluded 
to 'a possible linkage between shifts in values, logics and institutional change' (p. 425) in their study on accounting professionals but did not examine these linkages empirically. To our knowledge, this is the first study that unravels the practice of employed professionals' work and shows how shifts in social knowledge provoke unintended institutional change. Empirically, a unique dataset comprising of discovery documents in a recent court case helped us peel the layers of organizational secrecy to map with sufficient detail the nuanced and complex role routines that constitute managed professional work. Finally, going beyond most past studies, our study provides insights into the consequences of organizational efforts to structure professional work and the unintended institutional change it can provoke. We discuss the key contributions and implications below and close with limitations and future research directions.

\section{The LRA Framework of Organizational Control of Professional Work}

Several aspects of the proposed LRA framework underscore its usefulness in understanding organizational control of professional work. First, our perspective is that of a forprofit organization that holds agency in structuring institutional work that motivates, controls, and directs the professionals they employ for goal-directed action. Our thesis is that for-profit organizations that employ professionals for client engagement (e.g. banks, hospitals, consulting firms, pharmaceutical companies) can neither escape the plurality of their institutional fields nor legitimize their operations by subordinating or ignoring one of the logics. Creative institutional work that views professionalism as a resource rather than a restraint involves active internalization of the pluralistic logics by organizations. Second, the proposed framework posits that organizations institutionalize distinct roles corresponding to the pluralistic logics to ensure their translation into action via scripted role enactments. Roles then are scaffolds for institutionalizing norms, expectations, goals, and control systems that direct professionals' role enactments to align with the internalized logics. Third, our framework recognizes that pluralistic logics pose problems for institutional work due to the potential for contradictory role enactments. As such, we theorize that organizations control professional work by arbitrating role enactments that represent carefully scripted strategies and tactics for navigating the competing demands of pluralistic logics. Specifically, organizations script role enactments to evoke particular role interpretations among clients that legitimize organizational conformity with widely available institutional logics. Finally, we theorize that clients do not rely solely on cues from role enactments of professionals to infer role interpretations. Rather, clients interpret role enactments in the context of social knowledge they construct from community processes for collective understanding of the organizational motivations and goals underlying professional-client interactions. We specify conditions that induce gaps between scripted role enactments and role interpretations. In sum, the integration of institutional and role theories in the LRA framework offers a rich foundation to study the dynamics of institutional work that organizations structure to control professional work, and opens avenues for its further development and theorizing.

Dunn and Jones (2010, p. 139), among other institutional researchers, have noted that institutional fields with pluralistic logics are dynamic that move 'through periods of balance and imbalance ... [creating] an uneasy tension that is not easily resolved'. Our 
theorizing extends these ideas to include the dynamic interplay between commercial and communal logics in the larger institutional field, and its implications for organizational scripting of role enactments. Potentially in periods where commercial or communal logics dominate, organizational strategies for role enactments may be less complex and more transparent compared to periods where both logics reign in importance. What determines whether a particular logic will dominate or both logics will coexist? Greenwood et al. (2002) discuss the role of professional associations, which is particularly relevant. Most professionals organize around associations, just as commercial organizations participate in their own industry trade associations and interest groups. The organizational arbitrage of professional work occurs in the larger institutional field where corresponding professional associations contest to wrestle more autonomy for their constituents.

In drawing boundaries for our theory, we focused on contexts where professional autonomy is constrained and organizations hold asymmetric arbitrage power. This should not be assumed to mean that professionals are powerless even in these contexts. For instance, Sitkin and Sutcliffe (1991) found that pharmacists employed in the same organization displayed variability in information giving - those who individually adopted a commercial stance were less likely to provide information, while those who maintained a professional stance were prone to provide information. This suggests that professionals as individuals or as collectives can assert agency in deviating from organizationally scripted role enactments or contesting for alternative enactments. Future theorizing of our framework can benefit by enlarging it to include the perspectives of employed professionals and conceptualizing the internal contests for navigating the pluralistic logics.

\section{Scripted Role Enactments: Simple Displays, Complex Strategies}

Our findings provide empirical evidence of proactive exploitation of the wide repertoire of response templates available from internalizing the pluralistic logics to creatively weave diverse role enactment scripts. Specifically, we found that organizational strategies involved role scripting in two different domains - a public domain where role enactments are staged for display in physician interactions, and a private domain carefully shrouded from clients where role enactments fulfil the commercial interests of the organization. We identified four carefully developed strategies, each with elaborate tactics for achieving specific objectives. For each strategy and its associated tactics, role enactments were scripted to display role suppression where a closer role was suppressed and a consultant role was highlighted (evidence and education strategy), suppression of both the consultant and closer roles (surrogate strategy), and role incorporation (penetration strategy).

Two insights emerge from these findings. First, the organizational strategies and tactics uncovered generally evidenced preference for publicly displaying communal over commercial logics in professionals' role enactments. For instance, in the evidence-based strategy, displayed role enactments emphasized a consultant role while negating a closer role by supporting and disseminating 'untainted' scientific evidence. Likewise, in the surrogate selling strategy, displayed role enactment was intended for professionals to take a back seat 
by relinquishing both the consultant and closer roles while allowing physicians to take centre stage in sharing their experiences as peers. Wilful and careful scripting of role enactments to display active suppression of commercial intent was probably intended to ensure that physicians' interpretations were unambiguously categorized into a consultant role. Even where a role incorporation strategy was used (market penetration), role enactments were cleverly scripted to bring the consultant role to the fore while pushing the closer role to the background. Clearly, the organization calculus figured that a consultant role is more persuasive and compelling for physicians to categorize the professional work in a positive light and motivate favourable prescription writing.

Second, like the proverbial iceberg, the simplicity of displayed role enactments hid the underlying complexity of private role enactment plans that craftily interweaved the two roles. For instance, in the evidence strategy, professionals participated in producing scientific evidence favourable to the company's drugs while concealing the complicit role of the organization in its creation. The omission makes an unequivocal closer role look like an authentic consultant role. Likewise, in the surrogate selling strategy, crucial information that peers were carefully selected to act as Champions was purposely omitted, as was the financial reward provided to the Champions for their surrogate selling. These omissions obfuscated an unquestionable closer role by projecting a voluntary consultant in peer-to-peer interactions. By deliberately concealing the role complexity from public display, the organization's strategy for resolving conflict centred on directing professionals' displayed role enactments with contrived and complex plans for a closer masquerade as a consultant.

We conjecture that the role separation and switching are less preferable strategies because while separation increases client interaction costs (i.e. separate professionals for consultant and closer roles), role switching increases training and management costs by requiring complex public role displays that risk confounding role interpretations (i.e. hire, train, and manage professionals capable of effortlessly shifting between roles). Organizational choice in our study instead centred on complex strategies that required simple role displays.

In a recent study examining deceptive sales practices in a large financial service firm, MacLean and Behnam (2010, p. 1500) noted that organizations 'resolve the tension' of conflicted logics by 'deploying formal structures that meet institutional demands but are disconnected from actual practice' (see also Meyer and Rowan, 1977; Oliver, 1991). By contrast, Battilana and Dorado (2010, p. 1420) examine how commercial microfinance organizations 'deal internally with institutional pluralism' by developing hybrid structures that 'strike a balance between the logics' (see also Reay and Hinings, 2009). The organization in our study shows a variation on these themes by internalizing instead of decoupling communal and commercial logics and crafting a creative and intricate balancing of the pluralistic logics to develop hybrid role enactment plans (actual, not displayed). However, like in MacLean and Behnam's (2010) study, the organization apparently legitimizes its practices by ostensibly decoupling its consultant role enactments from closer role enactments so that only the former are visible to its clients. Decoupling in MacLean and Behnam's (2010) study eventually hollows out the organization's legitimacy claim by institutionalizing misconduct as its salespeople exploit the disregard for compliance. 
Our study suggests alternative possibilities. Potentially, professionals may reject organizational control of their professional work because they find it disingenuous. Evidence of PSPs blowing the whistle on their organizations, writing books that deride the strategies and tactics of the organizations that hire them (Reidy, 2005), and providing material for popular movies satirizing their hollow roles (e.g. Side Effects) indicates that PSPs find their professional cage oppressive and are attempting to assert their power to reclaim agency. Specifically, in the case we studied, the revelations of organizational strategies and the legal action that followed was prompted by a prominent professional who blew the whistle on practices he evidently found incongruent with professional norms. In other situations (e.g. accountants), employed professionals have attempted to stunt the power of organizations by evoking professional logics to preserve their autonomy (Scott, 2008). Evidently, PSPs have been less successful possibly because their professionalization is too nascent to thwart the power of organizations (von Nordenflycht, 2010). PSPs may also lack political astuteness to negotiate a space of autonomous agency in the organizations that employ them to shape their role enactments. Our study invites these possibilities as fruitful topics for future research.

\section{Glients' Social Knowledge as a Harbinger of Unintentional Institutional Change}

We find that institutional work by the organization we studied ultimately prompted widespread disruption of the very institutional structures that the organization intended to maintain and replicate. Evolving social knowledge and growing gaps between role interpretations and displayed role enactments seeded the forces of institutional change. Our study suggests that clients' role interpretations rely on social knowledge that is largely insulated from organizational influence. Social encoding of role enactments by clients evolves with changing social knowledge as shifts in public discourse surface new knowledge.

Institutional change is imminent when changes in social knowledge are so pervasive and profound that observers discard or deride previous encodings and reinterpret role enactments with fresh frames of social knowledge. These shifts are amplified by unrelenting evidence of organizational malfeasance from aggressive legal action and widespread and persistent reporting by news media. At some tipping point, public knowledge of organizational malfeasance may be so amplified that it evokes stigmatization through a shared consensus to disassociate, discredit, devalue, and attribute illegitimacy to an entity (Kurzban and Leary, 2001). Possibly, a similar pattern unfolded in our case study where the evidence of role incongruency took hold and prompted widespread re-categorization of institutional work by pharmaceutical organizations, reversing the significant gains in their legitimacy and provoking broad institutional change.

Our framework does not predict that disruption is inevitable and organizational pursuit of commercial interests is doomed. Only that inflexible and inauthentic role scripting in client interactions motivated by unfettered profit seeking makes organizations more not less susceptible to client (and public) backlash. Whether this backlash amplifies or abates depends on externalities that are outside organizational control, as exemplified by our study. While we have no direct evidence, we conjecture that authentic 
public displays of roles that recognize and not repress the underlying logics (e.g. role separation and role switching) may be more conducive to preventing client and public backlashes, and abating the effects of role incongruency when and if it arises in client interactions.

Our study contributes to the literature on institutional change processes by considering institutional work in the larger context of social interactions with organizational clients. Like previous studies of institutional change, we situate organizational legitimacy in external stakeholders (Kraatz and Block, 2008; Suchman, 1995). For instance, Reay and Hinings (2009) examine how change is legitimized as actors compete and collaborate around conflicting logics. Likewise, noting that 'understanding how institutional change occurs is a central challenge to institutionalist accounts', Greenwood et al. (2002, p. 76) show how professional associations legitimize change by a process of 'theorization' that includes the use of language, symbols, and artefacts. We extend these efforts by introducing the concepts of clients' social knowledge and role interpretations as mediators of institutional work and institutional change relationship. As role theoretic concepts that capture micro foundational aspects of organization-client interactions, social knowledge and role interpretations are rich constructs that can illuminate when and why an organization's well crafted strategy for gaining external legitimacy by reaffirming institutional logics backfires.

Moreover, our study argues for a systems perspective on institutional work by completing the loop that goes from logics to action (via roles) and then back from action to logics (via role interpretations and social knowledge). While the two parts of the loop respond to different mechanisms and forces, they together constitute an interdependent system. Physicians depend on pharmaceutical companies to develop innovative treatments and therapies that empower them to heal and improve the quality of life of their patients. Pharmaceutical companies depend on physicians for collaboration to develop and prescribe new treatments and therapies that promote patient health while offering economic returns. In such interdependent systems, internal setbacks or failures at any one node reverberate throughout the system (March and Olsen, 1998). Our LRA framework draws attention to these interdependencies. Like the proverbial trap of digging deeper to find a way out, our study suggests that the more the professional work narrowed its displays on communal logic to win physician and public legitimacy, the more profound the likely institutional change when the strategic cover is unveiled. Unable to grasp this system view, organizations inadvertently disrupt the very institutional structures that they seek to maintain and replicate. Future studies are likely to yield incomplete analysis and misleading insights unless they adopt a systems perspective. Our LRA framework provides a theoretically sound and pragmatically useful starting point for such studies.

\section{Study Limitations}

Because this study is based on interpretive analysis of a case study, the results are useful for insights into theoretical mechanisms rather than for generalizable patterns of practice. The reported mechanisms are best viewed as explanations that fit the puzzle rather 
than as irrefutable proof of proposed effects. Although our unique case study data uncovers pieces of puzzle that are usually shrouded or suppressed from scrutiny, we encourage future research that provides robust evidence of proposed mechanisms.

In addition, the data used in the study do not include first-hand accounts from actors. Verbatim reports in legal testimonies of key actors are included in the study, but direct interviews for the purposes of this study are not. Several concerns made such attempts unattractive, including access to key actors who have since moved on, and the potential for recovery and reporting biases due to the high level of publicity that followed court settlement and subsequent disclosures. To this extent, our results infer intentionality but do not confirm it.

Notably, our study examines the institutional dynamics related to professional work in the pharmaceutical industry over a period stretching from 2003 to 2010. Institutional change unfolds as a slow motion process. Patterns observed over a seven-year period may be open to alternative interpretations when framed in a perspective with longer spans. Are for-profit organizations inevitably doomed by a fatal dance of commercial and communal logics in scripted roles for professional work? Or is there a Solomonistic path to navigate successfully through the competing logics without forsaking one for the other? Are some industries and organizations, like the pharmaceutical company examined in this study, especially susceptible to these dilemmas? Indeed, one purpose of our analysis is to encourage managers in for-profit organizations to be imaginative and creative in developing paths for successful navigation of competing logics, as it is to highlight the perils along the path. Nevertheless, more research is needed to examine these questions in other contexts and across wider swaths of time to obtain comprehensive accounts of institutional dynamics.

In closing, we note that our study holds broader relevance to managed professional work in fields as diverse as health care and engineering. We hope that our study provides the impetus for future research that offers managerial insights to effectively navigate the competing logics by collaborating with professionals to design institutional work for sustainable organizational return and legitimacy.

\section{NOTES}

[1] A PSP's distinctive knowledge involves three interrelated domains: (1) Clinical and Medical Knowledge (e.g. Anatomy, Clinical Pharmacology, Pharmacokinetics, Package Insert Information, Clinical Trials, Toxicology); (2) Regulatory Environment (e.g. laws enforced by the FDA, Compliance in Drug Labelling and Promotion, Patent law); and (3) Selling Skills (e.g. Relationship Selling, Territory Planning, Drug Logistics and Transportation, Brand Management).

[2] In the literature, role interpretations by clients or observers who attend to cues in the professional's role enactments to infer the corresponding, socially coded, role category displayed are referred to as 'correspondent inferences' (Howard, 1985; Jones and Davis, 1965). Our framework posits that clients' correspondent inferences engage their social knowledge and are not wholly dependent on organizational orchestration of professional role enactments.

[3] Referred exhibits pertain to materials included in the court documents related to United States ex rel. David Franklin vs. Parke-Davis, 147 F. Supp.2d 39 and are available at http://dida.library.ucsf.edu.

[4] The five states are Minnesota, California, Maine, Vermont, and West Virginia.

[5] The Physician Payment Sunshine provisions were included in the Patient Protection and Affordable Care Act of 2009 (H.R. 3590, section 6002) which was signed into law on 23 March 2010. 


\section{REFERENCES}

Abbott, A. (1988). The System of Professions: An Essay on the Division of Expert Labor. Chicago, IL: University of Chicago Press.

Abelson, R. (2006). 'New nerve test, a moneymaker, divides doctors'. New York Times, 20 October, B1.

Aggarwal, P. and Law, S. (2005). 'Role of relationship norms in processing brand information'. Fournal of Consumer Research, 32, 453-64.

Alvesson, M. and Johansson, A. W. (2002). 'Professionalism and politics in management consultancy work'. In Clark, T. and Fincham, R. (Eds), Critical Consulting: New Perspectives on the Management Advice Industry. Oxford: Blackwell, 228-46.

Anderson, E. and Oliver, R. (1987). 'Perspectives on behavior-based versus outcome-based sales control systems'. Journal of Marketing, 51, 76-88.

Angell, M. (2005). The Truth about the Drug Companies: How They Deceive Us and What to Do About It. New York: Random House.

Arnold, M. (2010). 'Pharma's got a brand new bag'. Medical Marketing and Media, 5, 34-7.

Arrow, K. J. (1994). 'Methodological individualism and social knowledge'. American Economic Review, 84, $1-9$.

Ashforth, B. E. (2001). Role Transitions in Organizational Life: An Identity-Based Perspective. Mahwah, NJ: Erlbaum.

Barley, S. R. and Kunda, G. (1992). 'Design and devotion: surges of rational and normative ideologies of control in managerial discourse'. Administrative Science Quarterly, 37, 363-99.

Barley, S. R. and Tolbert, P. S. (1997). 'Institutionalization and structuration: studying the links between action and institution'. Organization Studies, 18, 93-117.

Battilana, J. and Dorado, S. (2010). 'Building sustainable hybrid organizations: the case of commercial microfinance organizations'. Academy of Management fournal, 53, 1419-40.

Berenson, A. (2006). 'In the money and in court'. New York Times, 30 August, C1.

Blatt, R. (2009). 'Tough love: how communal schemas and contracting practices build relational capital in entrepreneurial teams'. Academy of Management Review, 34, 533-51.

Brint, S. (1994). In the Age of Experts: The Changing Role of Professionals in Politics and Public Life. Princeton, NJ: Princeton University Press.

Broadbent, J., Dietrich, M. and Roberts, J. (1997). The End of the Professions? The Restructuring of Professional Work. New York: Routledge.

Brock, D. M. (2006). 'The changing professional organization: a review of competing archetypes'. International Journal of Management Reviews, 8, 157-74.

Bruner, J. (1990). Acts of Meaning. Cambridge, MA: Harvard University Press.

Carlat, D. (2006). 'Generic smear campaign'. New York Times. 9 May, B1.

Caronna, C. (2004). 'The misalignment of institutional "pillars": consequences for the U.S. health care field'. Journal of Health and Social Behavior, 45, 45-58.

Carreyrou, J. (2006). 'Cephalon used improper tactics to sell drug, probe finds'. Wall Street Fournal, 21 November, B1.

Clark, M., Fitness, J. and Brissette, I. (2001). 'Understanding people's perceptions of relationships is crucial to understanding their emotional lives'. In Fletcher, G. J. O. and Clark, M. (Eds), Handbook of Social Psychology. Vol 2: Interpersonal Processes. Oxford: Blackwell Publishers, 253-78.

Cooper, D. J. and Robson, K. (2006). 'Accounting, professions, and regulation: locating the sites of professionalism'. Accounting, Organizations, and Society, 31, 415-44.

Cooper, D. J., Hinings, G. R., Greenwood, R. and Brown, J. L. (1996). 'Sedimentation and transformation in organizational change: the case of Canadian law firms'. Organization Studies, 17, 623-47.

Croasdale, M. (2006). 'Some medical schools say no to drug reps' free lunch'. American Medical News, 9 October, P1.

Datamonitor (2006). Pharmaceuticals in the United States: Industry Profile. New York: Datamonitor.

Davis, J., Schoorman, D. and Donaldson, L. (1997). 'Toward a stewardship theory of management'. Academy of Management Review, 22, 20-47.

Dunn, M. B. and Jones, C. (2010). 'Institutional logics and institutional pluralism: the contestation of care and science logics in medical education, 1967-2005'. Administrative Science Quarterly, 55, $114-49$.

Elling, M., Simon, C. and McKhann, C. (2002). 'Making more of pharma's sales force'. McKinsey Quarterly, August, 86-95.

Evetts, J. (2011). 'A new professionalism? Challenges and opportunities'. Current Sociology, 59, 406-22.

Faulconbridge, J. and Muzio, D. (2008). 'Organizational professionalism in globalizing law firms'. Work, Employment, and Society, 22, 7-25. 
Flanagin, A., Fontanarosa, P. B. and DeAngelis, C. D. (2006). 'Update on JAMA's conflict of interest policy'. Fournal of the American Medical Association, 296, 220-1.

Friedland, R. and Alford, R. R. (1991). 'Bringing society back in: symbols, practices, and institutional contradictions'. In Powell, W. W. and DiMaggio, P. J. (Eds), The Nerw Institutionalism in Organizational Analysis. Chicago, IL: University of Chicago Press, 232-63.

Frith, C. D. and Frith, U. (2012). 'Mechanisms of social cognition'. Annual Review of Psychology, 63, 287313.

Giddens, A. (1976). New Rules of Sociological Method: A Positive Critique of Interpretive Sociologies. Oxford: Hutchinson.

Glynn, M. A. (2008). 'Beyond constraint: how institutions enable identities'. In Greenwood, R., Oliver, G., Sahlin-Anderson, K. and Suddaby, R. (Eds), The Sage Handbook of Organizational Institutionalism. London: Sage, 413-30.

Glynn, M. A. and Lounsbury, M. (2005). 'From the critics' corner: logic blending, discursive change and authenticity in a cultural production system'. Fournal of Management Studies, 42, 1031-55.

Goffman, E. (1983). 'The interaction order: American Sociological Association 1982 presidential address'. American Sociological Reviewe, 48, 1-17.

Greene, J. A. (2004). 'Attention to details: etiquette and the pharmaceutical salesman in postwar America'. Social Studies of Science, 34, 271-92.

Greenwood, R. and Suddaby, R. (2006). 'Institutional entrepreneurship in mature fields: the Big Five accounting firms'. Academy of Management Fournal, 49, 27-48.

Greenwood, R., Suddaby, R. and Hinings, G. R. (2002). 'Theorizing change: the role of professional associations in the transformation of institutional fields'. Academy of Management Fournal, 45, 58-80.

Haveman, H. A. and Rao, H. (1997). 'Structuring a theory of moral sentiments: institutional and organizational co-evolution in the early thrift industry'. American Fournal of Sociology, 102, 1608-51.

Haveman, H. A. and Rao, H. (2006). 'Hybrid forms and the evolution of thrifts'. American Behavioral Scientist, 49, 974-86.

Haveman, H. A., Rao, H. and Paruchuri, S. (2007). 'The winds of change: the progressive movement and the bureaucratization of thrift'. American Sociological Reviewe, 72, 117-42.

Healy, D. and Cattell, D. (2003). 'Interface between authorship, industry and science in the domain of therapeutics'. British fournal of Psychiatry, 183, 22-7.

Howard, J. A. (1985). 'Further appraisal of correspondent inference theory'. Personality and Social Psychology Bulletin., 11, 467-77.

Jarzabkowski, P., Matthiesen, J. and Van De Ven, A. (2009). 'Doing which work? A practice approach to institutional pluralism'. In Lawrence, T., Leca, B. and Suddaby, R. (Eds), Institutional Work: Actors and Agency in Institutional Studies of Organizations. Cambridge: Cambridge University Press, 284-316.

Jones, C. and Livne-Tarandach, R. (2008). 'Designing a frame: rhetorical strategies of architects'. Fournal of Organizational Behavior, 29, 1075-99.

Jones, E. E. and Davis, K. E. (1965). 'From acts to dispositions: the attribution process in person perception'. In Berkowiz, L. (Ed.), Advances in Experimental Social Psychology. New York: Academic press, 219-66.

Kipping, M. (2011). 'Hollow from the start? Image professionalism in management consulting'. Current Sociology, 59, 530-50.

Kraatz, M. and Block, E. (2008). 'Organizational implications of institutional pluralism'. In Greenwood, R., Oliver, C., Sahlin-Anderson, K. and Suddaby, R. (Eds), Sage Handbook of Organizational Institutionalism. London: Sage, 243-75.

Kurzban, R. and Leary, M. R. (2001). 'Evolutionary origins of stigmatization: the functions of social exclusion'. Psychological Bulletin, 127, 187-208.

Landefeld, C. S. and Steinman, M. A. (2009). 'The Neurontin legacy - marketing through misinformation and manipulation'. New England Fournal of Medicine, 360, 103-06.

Lawrence, T. B., Suddaby, R. and Leca, B. (2009). 'Introduction: theorizing and studying institutional work'. In Lawrence, T. B., Suddaby, R. and Leca, B. (Eds), Institutional Work: Actors and Agency in Institutional Studies of Organizations. Cambridge: Cambridge University Press, 31-58.

Leicht, K. T. and Fennell, M. L. (1997). 'The changing organizational context of professional work'. Annual Review of Sociology, 23, 215-31.

Lillard, A. S. (1997). 'Other folks' theories of mind and behavior'. Psychological Science, 8, 268-74.

Lounsbury, M. (2002). 'Institutional transformation and status mobility: the professionalization of the field of finance'. Academy of Management Fournal, 45, 255-66.

Lounsbury, M. (2007). 'A tale of two cities: competing logics and practice variation in the professionalizing of mutual funds'. Academy of Management Fournal, 50, 289-307. 
MacLean, T. L. and Behnam, M. (2010). 'The dangers of decoupling: the relationship between compliance programs, legitimacy perceptions, and institutionalized misconduct'. Academy of Management Fournal, 53, 1499-520.

March,J. G. and Olsen, J. P. (1998). 'The institutional dynamics of international political orders'. International Organization, 52, 943-69.

Marquis, C. and Lounsbury, M. (2007). 'Vive La Résistance: competing logics and the consolidation of U.S. community banking'. Academy of Management Fournal, 50, 799-820.

Mathews, A. W. (2005). 'At medical journals, writers paid by industry play big role'. Wall Street fournal, 13 December, B1.

Meyer, J. W. and Hammerschmid, G. (2006). 'Changing institutional logics and executive identities: a managerial challenge to public administration in Austria'. Academy of Management Fournal, 49, 100014.

Meyer, J. W. and Rowan, B. (1977). 'Institutionalized organizations: formal structure as myth and ceremony'. American Fournal of Sociology, 83, 340-63.

Murray, M. T. (2010). What the Drug Companies Won't Tell You and Your Doctor Doesn't Know. New York: Atria Books.

Nigam, A. and Ocasio, W. (2010). 'Event attention, environmental sense making, and change in institutional logics: an inductive analysis of the effects of public attention to Clinton's health care reform initiative'. Organization Science, 21, 823-41.

Novartis (2012). Mission statement. Available at http://www.novartis.com/about-novartis/our-mission/ index.shtml (accessed 6 October 2012).

Oliver, C. (1991). 'Strategic responses to institutional processes'. Academy of Management Review, 16, 145-79.

Perner, J. (1999). 'Theory of mind'. In Bennett, M. (Ed.), Developmental Psychology: Achievements \&O Prospects. Hove: Psychology Press, 205-30.

Petersen, M. (2008). Our Daily Meds: How the Pharmaceutical Companies Transformed Themselves into Slick Marketing Machines and Hooked the Nation on Prescription Drugs. New York: Farrar, Straus and Giroux.

Pratt, M. G. and Kraatz, M. S. (2009). 'E pluribus unum: multiple identities and the organizational self'. In Dutton, J. and Roberts, L. M. (Eds), Exploring Positive Identities and Organizations: Building a Theoretical and Research Foundation. New York: Psychology Press, 377-402.

Premack, D. and Woodruff, G. (1978). 'Does the chimpanzee have a theory of mind?'. The Behavioral and Brain Sciences, 1, 515-26.

Psaty, B. M. and Kronmal, R. A. (2008). "Reporting mortality findings in trials of Rofecoxib for Alzheimer disease or cognitive impairment'. Fournal of the American Medical Association, 299, 1813-17.

Purdy, J. M. and Gray, B. (2009). 'Conflicting logics, mechanisms of diffusion, and multi-level dynamics in emerging institutional fields'. Academy of Management Fournal, 52, 355-80.

Rao, H., Monin, P. and Durand, R. (2003). 'Institutional change in Toque Ville: nouvelle cuisine as an identity movement in French gastronomy'. American Fournal of Sociology, 108, 795-843.

Reay, T. and Hinings, C. R. (2009). 'Managing the rivalry of competing institutional logics'. Organization Studies, 30, 629-52.

Reidy, J. (2005). Hard Sell. Kansas City, MO: Andrews McMeel Publishing.

Ross, J. S., Hill, K. P., Egilman, D. S. and Krimholz, H. M. (2008). 'Guest authorship and ghostwriting in publications related to Rofecoxib: a case study of industry documents from Rofecoxib litigation'. Fournal of the American Medical Association, 299, 1800-12.

Ryals, L. and Davies, I. (2010). 'Do you really know who your best salespeople are'. Harvard Business Reviere, 88, 34-5.

Scott, W. R. (2001). Institutions and Organizations, 2nd edn. Thousand Oaks, CA: Sage.

Scott, W. R. (2008). 'Lords of the dance: professionals as institutional agents'. Organization Studies, 29, 219-38.

Settles, I. H., Sellers, R. M. and Damas, A. Jr (2002). 'One role or two? The function of psychological separation in role conflict'. Fournal of Applied Psychology, 87, 574-82.

Sitkin, S. and Sutcliffe, K. (1991). 'Dispensing legitimacy: professional, organizational and legal influences on pharmacist behavior'. Research in the Sociology of Organizations, 8, 269-95.

Steinman, M. A., Bero, L. A., Chren, M. M. and Landefeld, S. (2006). 'The promotion of gabapentin: an analysis of internal industry documents'. Annals of Internal Medicine, 145, 284-93.

Stryker, S. and Statham, A. (1985). 'Symbolic interaction and role theory'. In Lindzey, G. and Aronson, E. (Eds), Handbook of Social Psychology. Hillsdale, NJ: Random House, 311-78.

Suchman, M. (1995). 'Managing legitimacy: strategic and institutional approaches'. Academy of Management Revierw, 20, 571-610.

Suddaby, R. (2010). 'Challenges for institutional theory'. Fournal of Management Inquiry, 19, 14-20. 
Suddaby, R. and Greenwood, R. (2005). 'Rhetorical strategies of legitimacy'. Administrative Science Quarterly, 50, 35-67.

Suddaby, R., Gendron, Y. and Lam, H. (2009). 'The organizational context of professionalism in accounting'. Accounting, Organizations and Society, 34, 409-27.

Thornton, P. H. (2002). 'The rise of the corporation in a craft industry: conflict and conformity in institutional logics'. Academy of Management Fournal, 45, 81-101.

Thornton, P. H. and Ocasio, W. (1999). 'Institutional logics and the historical contingency of power in organizations: executive succession in the higher education publishing industry, 1958-1990'. American Journal of Sociology, 105, 801-43.

Thornton, P. H. and Ocasio, W. (2008). 'Institutional logics'. In Greenwood, R., Oliver, C., SahlinAndersson, K. and Suddaby, R. (Eds), The Sage Handbook of Organizational Institutionalism. London: Sage, 99-129.

von Nordenflycht, A. (2010). 'What is a professional service firm? A theory and taxonomy of knowledge intensive firms'. Academy of Management Review, 35, 155-74.

Weber, M. (1978). Economy and Society. Berkeley, CA: University of California Press.

Weitz, B. and Bradford, K. D. (1999). 'Personal selling and sales management: a relationship marketing perspective'. Fournal of the Academy of Marketing Science, 27, 241-54.

Wellman, H. M. (1993). 'Early understanding of mind: the normal case'. In Baron-Cohen, S., TagerFlusberg, H. and Cohen, D. (Eds), Understanding Other Minds: Perspectives from Autism. Oxford: Oxford University Press, 10-39.

Zietsma, C. and Lawrence, T. B. (2010). 'Institutional work in the transformation of an organizational field: the interplay of boundary work and practice work'. Administrative Science Quarterly, 55, 189-221. 